\title{
Decipher Global Trade Model: the Macroeconomic Policy Implications
}

\author{
Jong-Eun Lee*
}

\begin{abstract}
The purpose of this study is to provide down-to-earth macroeconomic policy implications from the up-to-date estimates of the trade system in the OECD countries. Understanding on the linkages between the world trade mechanism and the macroeconomy is of utmost importance for the post-crisis managements of the world economy, the major points regarding the macroeconomic policy implications are as follows.

(1) For the majority of the OECD countries, fiscal expansion is likely to encourage the world trade when it is designed in the way to increase private consumption, in fact, only in a few countries fiscal expansion can increase the world trade volumes in its own right.

(2) Currency depreciation might be an attractive policy option for improving trade balances in the cases of the 9 OECD countries.

(3) There is a clear evidence of pricing-to-market with cross-country diversity, implying that import or domestic price robustness from the external forces.
\end{abstract}

Key Word: Global Trade Model; the OECD countries; Macroeconomic Policy

JEL codes: F10, F14, F41

* Corresponding Address: LEE, Jong-Eun, Professor, Department of Economics, Sejong University, 98 Gunja-Dong, Gwangjin-Gu, Seoul, 143-747, Republic of Korea. Email: LJONGEUN@sejong.ac.kr Tel:+82-2-3408-3137 Fax: +82-2-3408-4306

This first draft has been done at the Economic Deparment, OECD during the sabbatical year of the author at the request of the OECD Secretariat. All views and errors are author's. 


\section{Introduction}

The financial crisis started from the second half of 2008 was seemingly followed by one of the most synchronized recession and the subsequent world-wide trade contraction, but the excessive financial risk-takings falling short of prudent supervisions in the developed economies are not possible without the global balance of payments imbalances. In this regard, the up-to-date and down-to-earth understanding on the world trade mechanism is indispensable for the post-crisis managements of the global economy. This paper, therefore, refrains from being complacent with the theoretically reasonable results and attempts to capture the salient features in the export volume, import volume, export price, and import price systems in the OECD economy as main object of examination and also in the non-OECD economy as far as the data allows.

Estimates based on the data from the first quarter of 1982 up to the fourth quarter of 2008 are of value in its own right since the data covers the financial crisis period, particularly the notable trade collapse in the third and fourth quarter of 2008. Also, it is meaningful in that it is a continuation of the works done by Nigel et al. (2005) based on the Organization of Economic Cooperation and Development (OECD) Secretariat's World Trade Model, although some changes are made in this paper. Similar works related to the world trade model can be seen in Haas and Turner(1990), Deppler and Ripley(1978), and Spencer(1984) with the specifications of the International Monetary Fund's(IMF) World Trade Model and more recently Global Vector Auto Regression model in by Bussiere et al.(2009). Specifications of model and the degrees of data disaggregations are certainly different by authors, with each having its own merits, but, as a matter of fact, the value of this kind of re-estimation works mostly lies in the interpretations of results.

In the paper, our special attention will be given to the long-term linkages of the import volume and the GDP components. It is the key transmission mechanism of international trade and global macro-economy and this study particularly highlights that the basic consumer theory is not necessarily relevant in understanding the movements of import volumes. For the majority of the OECD countries, fiscal expansion is likely to encourage the world trade when it is designed in the way to increase private consumption, in fact, only in a few countries fiscal expansion is found to increase the world trade volumes in its own right.

Second, pricing-to-market versus purchasing power parity will be examined. It shows the nature of import markets in the OECD countries such as the degree of national market segmentation from the rest of the world. From the macroeconomic perspectives, pricing-to-market gives an monetary authority the independent scope from the foreign 
prices to some extent. In the majority of the OECD countries, however, the magnitude of cost-based pricing is greater than that of pricing-to-market but there is a cross-country diversity.

Third, the Marshall-Lerner condition versus J-curve effect deserves our attention. Given the frequent cross-border rows on the exchange rates and the significance of trade balance as reflecting the core of international competitiveness and the vulnerability of possible currency crisis, the long-term Marshall-Lerner condition on the OECD countries is not a minor issue. It offers the basic information on the exchange rate and monetary policy in the open macro-economy. Currency depreciation might be an attractive policy option for improving trade balances for the 9 OECD countries.

The remaining part of this paper is organized as follows; sections 2 describes estimation strategy, sections 3 to 5 present results for export volume system, import volume system, export and import price systems, section 6 concludes.

\section{Estimation Strategy}

A number of trade equation systems are estimated, i.e., export volume, import volume, export price, and import price systems for the OECD countries. In our sample, all of the 30 OECD member countries are included. Among them, the 13 countries belong to the euro area such as Austria, Belgium, France, Finland, Germany, Greece, Ireland, Italy, Luxembourg, the Netherlands, Portugal, Slovak Republic, and Spain but Czech Republic, Denmark, Hungary, Poland, Sweden, and the United Kingdom are the European Union member countries that do not belong to the euro area.

The data are obtained from the OECD Statistics with the base year of 2005, and the variable definitions for each trade equation remain the same as in Nigel et al.(2005) and also fully explained in the main text alongside appendix in this paper.

Basic equations are composed of short-run dynamics and cointegrating relationships. This paper puts the highest priority on the best reflection of the data incorporating all country-specific characteristics at the expense of simplicity across countries. So, however small the country is, the equation is reflecting the parameter restriction tests, if there is any parameter constraint. To exploit any information on the correlations between contemporaneous errors across countries, the seemingly unrelated regression estimates have been computed for each trade equation system such as export volume, import volume, export price, and import price equation systems. Each system comprises the preferred single equations for each country. 
Country-specific time dummies are allowed for capturing period-specific or country-specific shocks, fulfilling the basic assumptions of residuals in the regressions. The period for the estimation is from the first quarter of 1982 to the fourth quarter of 2008 covering the recessions in 1982, 2001, 2008, and the major events such as the Plaza Accord in 1985, the fall of the Communist block and German unification shocks over the period of the late 1980s to the early 1990s, European single market in 1992, the Asian financial crisis in 1997, the Russian financial crisis in 1998, the Information Technology bubble bursts and 9/11 terror in 2001, and the recent financial crisis and subsequent trade collapse in 2008. For Germany after the unification and a few Eastern European countries such as Czech Republic, Hungary, Poland, and Slovak Republic, the data start from 1991. One can see the stability aspect of our trade equation systems by dummy variables bearing these historical occasions in mind.

As revealed in figure 1, the quarters in the year 2008 need absolutely greatest number of dummies than any other period, i.e., requiring 21 dummies, followed by the third quarter of 1983 and the fourth quarter of 1990 with each requiring 6 dummies which are possibly related to the recession period started in 1982, and to the fall of the Communist block and the German unification shocks respectively. The updated regressions of the post-crisis with the extended data in the future might reveal whether this period was truly exceptional (keeping the simialr number of dummies) or whether the global trade mechanism is substantially changed and thus fully reflected on the re-estimated parameters in the future (keeping less dummies). Nevertheless, one can currently observe the exceptionality of the recent financial crisis shocks from the number of dummies in 2008. Besides, comparing trade equations, dummy variables in 2008 are more required in the price equations than volume equations as expected from the fact that price mechanism is more sensitive to shocks than quantity responses.

\section{Export Volume}

The export volume equation has the form as equation (1) comprising short-run dynamics and the long-run relationship.

$$
\begin{aligned}
& d \ln \left(X_{i t}\right)=\theta_{1 i}+\theta_{2 i} d \ln \left(X_{i, t-1}\right)+\theta_{3 i} d \ln \left(W_{i t}\right)+\theta_{4 i} d \ln \left(W_{i, t-1}\right)+\theta_{5 i} d \ln \left(R P X_{i t}\right)+\theta_{6 i} d \ln \left(R P X_{i, t-1}\right) \\
& +\theta_{7 i}\left[\ln \left(X_{i, t-1}\right)-\theta_{11 i} \ln \left(W_{i, t-1}\right)-\theta_{8 i} \ln \left(R P X_{i, t-1}\right)-\theta_{9 i} t i m e_{t-1}-\theta_{10 i} \ln \left(t i m e_{t-1}\right)\right] \\
& +\varepsilon_{i t}
\end{aligned}
$$


where $X$ denotes the volume of exported goods and services in country $i, \mathrm{~W}$ is the measure of export market for country $i$ (see appendix for the detailed definition). $R P X$ denotes the price of exported goods and services relative to competitors' prices, and time stands for a deterministic function of time. The trend function of time is supposed to capture omitted factors.

The null hypothesis of a long run elasticity of unity, i.e., $\theta_{11 i}=1$ for the export market size, is imposed only for the countries of which data accept the null hypothesis; for a number of countries, export market sizes do not explain export volumes in the long-run relationship. Czech Republic, Finland, Turkey, New Zealand, and Norway are the cases ${ }^{1)}$; Belgium(0.566), Italy(0.488), Japan(0.715) have less than unit elasticity; as an emerging economy, Hungary(2.465) shows more than unity at the 1 percent significance level; the rest of the OECD countries accept the null hypothesis, so their export market shares are pinned down as in Murata et al.(2000) and Nigel et al.(2005). It is interesting in the sense that not every country has export volume closely tied to its overall export market share in the world market showing a sign of dynamism in the world export evolvements.

All error correction terms are significant except the United Kingdom, suggesting that a statistically significant long-run relationship exists for most of the OECD countries.

The price-elastic responses of export volumes in the long-term relationship are found in Czech Republic(-1.237), Finland(-1.254), Iceland(-1.996\%), Japan(-1.027), Korea(-1.45\%). Spain(-1.209), and Switzerland(-1.331), i.e., having elasticities greater than unity. Insignificant long-term price elasticity is found in Belgium, Denmark, Hungary, Ireland, Luxembroug, Mexico, Portugal, Turkey, and the United Kingdom. In particular, the elasiticty in Mexico turned into being insignificant from the elasticity above unity in the previous estimation of Nigel et al.(2005). Most of the remaining countries have elasticities in the range of -0.4 to $-1 \%$ higher than the previous range of -0.2 to $-1 \%$, suggesting that the export volumes in the OECD economy becomes more price elastic than before. Germany as one of the world's heaviest exporters, has remained as having the smallest elasticity amongst the G7, $-0.419 \%$, similar in Nigel et al.(2005).

Except Finland, Greece, Iceland, Mexico, and the United Kingdom, statistically significant coefficients are found on the time trend components, implying that there are significant variations over time in export performances of the OECD countries after controlling other factors. In the previous estimation, Denmark, Finland, Iceland, Luxembourg, and Sweden have been without any trend effects, suggesting that the trend term has not been explaining the export volumes in Finland and Iceland since the previous estimation. Decreasing trend of export volume towards the year 2015 is majority in the

1) For Norway, it was insignificant at the $5 \%$ significance level 
OECD economy and increasing trends of export volumes towards 2015 are found in about the one third of the OECD countries such as Czech Republic, Germany, Ireland, Luxembourg, Norway, New Zealand, Poland, Slovak Republic, and Turkey. In Germany, the trend dramatically turns decreasing into increasing since the year 2000, i.e., seemingly an inflexion point, suggesting that the German export competitiveness is likely to be recovered from the higher unit wage costs by the unification shocks.

\section{Import volume}

Our import volume equation (2) contains the GDP components that are supposed to function as main sources of import demands. The GDP components in equation (2) such as private consumption, government consumption, investment, export, and import demands, constitute the GDP by definition, so estimates in the long-run relationship can offer macroeconomic implications in the way of revealing the elasticities of imports with respect to other GDP components. The information is of utmost importance from the perspective of the international trade transmission effects and the recovery from the financial crisis. In particular, the import volume response to government consumption is of interests since it reveals the impacts of fiscal policy on the import volumes, i.e., export volume from the rest of the world as the other side of coin.

Our import volume equation expressed in equation (2), is composed of short-run dynamics and cointegrating relationship with the error correction term, $\Phi_{10 i}$.

$$
\begin{aligned}
& d \ln \left(M_{i t}\right)=\phi_{1 i}+\phi_{2 i} d \ln \left(C_{i t}\right)+\phi_{3 i} d \ln \left(G_{i t}\right)+\phi_{4 i} d \ln \left(I_{i t}\right)+\phi_{5 i} d \ln \left(X_{i t}\right) \\
& +\phi_{6 i} d \ln \left(M_{i, t-1}\right)+\phi_{7 i} d \ln \left(M_{i, t-2}\right)+\phi_{8 i} d \ln \left(R P M_{i t}\right)+\phi_{9 i} d \ln \left(R P M_{i t-1}\right) \\
& +\phi_{20 i} d\left(\ln \left(C_{i t}\right) \ln \left(G_{i t}\right)\right)+\phi_{2 l i} d\left(\ln \left(C_{i t-1}\right) \ln \left(G_{i t-1}\right)\right) \\
& +\phi_{10 i}\left[\begin{array}{l}
\ln \left(M_{i, t-1}\right)-\phi_{11 i} \ln \left(C_{i, t-1}\right)-\phi_{12 i} \ln \left(G_{i, t-1}\right)-\phi_{13 i} \ln \left(I_{i, t-1}\right)-\left(1-\phi_{11 i}-\phi_{12 i}-\phi_{13 i}\right) \ln \left(X_{i, t-1}\right) \\
-\phi_{15 i} \ln \left(R P M_{i, t-1}\right)-\phi_{16 i} i e_{t-1}-\phi_{17 i} \ln \left(t i m e_{t-1}\right)-\phi_{20 i}\left(\ln \left(C_{i t-1}\right) \ln \left(G_{i t-1}\right)\right)
\end{array}\right] \\
& +\mu_{i t}
\end{aligned}
$$

where $\mathrm{M}$ stands for the volume of imported goods and services in country $i, C$ and $G$ denote private and government final consumptions, $I$ denotes total fixed investment plus stockbuilding, RPM denotes the price of imported goods and services relative to domestically produced goods and services as given by the GDP deflator, and time denotes a deterministic function of time. 
Positive signs for the GDP components and negative signs for the relative import prices in the long-term relationship are expected when one follows the basic consumer's demand theory, but at the macroeconomic level, we need to consider beyond that.

For example, during the course of the estimations, the necessity to reflect intertwined relationship between private and government consumption has been strongly perceived. It is not surprising because government consumption basically needs to be financed by taxes, bonds, or money-printing, and moreover, the personnel expenses in the government consumption take substantial parts of expenditure $(54.5 \%$ on average for the OECD countries for the longest period available). So, there could be a number of dynamic channels to influence private consumptions through wealth and income effects of which the long-term version is the well-known Ricardian Equivalence (Ganelli 2007, Canzoneri et al.2002, Blanchard and Perotti 2002). From this macroeconomic perspective, the private and government consumptions could be intertwined and seemingly behave as complements or substitutes, leading to influence import demands. The interaction term of private and government consumptions is added in equation (2) to capture this macroeconomic effects. The additional inseparability between private and public goods can be also thought as the literature claims(Fiorito and Kollintzas 2004, Linnemann and Schabert 2004). It is likely to be the question of crowding-out versus crowding-in of private consumption by government consumption, which can be traced back to the debates between monetarists and Keynesians, as well illustrated in Blinder and Solow(1973).

Moreover, the addition of interaction terms also makes a long-run elasticity of unity, $\Phi_{14 i}=1-\Phi_{11 i}-\Phi_{12 i}-\Phi_{13 i}$, be accepted by all the OECD countries. In fact, without interaction term, this unity restrictions are rejected in a number of countries including the United Kingdom. This signifies that import penetration can be bounded only when intertwined relationship between private and government consumptions is taken into account in the current estimation. This is a departure from the equation specifications in Nigel et al.(2005) where a long-run elasticity of unity was reasonably accepted by the dat a. ${ }^{2)}$

Further simplicity can be thought by imposing more restrictions among private consumption, government consumption, and investment demands as used in the previous estimation both in the long-term relationships and in short-run dynamics, but these parameter restrictions are strongly rejected in the majority of the OECD countries including the United States unlike in Nigel et al.(2005), so this paper does not consider imposing further parameter restrictions on import volume equation. It is also confirming that the data

2) For the overall coherence of longer-term model properties, one had better keep a long-run elasticity of unity that can pin down import penetration, if not indispensable. In this regard, our result on a long-run elasticity of unity is promising. 
for the current estimation requires us to reflect the intertwined relationship between private and government consumptions rather than further linear constraints of parameters among the different GDP components.

Not every elasticity of the GDP component in the long-term relationship is significant. In the long-term relationship, the coefficients for private consumptions in the 14 OECD countries, for investment demands in the 22 countries, and for government consumptions in the 8 countries are found to be significant. In the short dynamic terms, 28 countries have significant coefficients for investment demands, 26 countries for export demands whereas private and government consumptions are found to be significant only in 14 and 10 countries respectively. It gives us an impression that the relative importance in explaining the long-term movements of import volumes are not homogenous across the GDP components, i.e, more explained by investment demands or export demands rather than private or government consumptions.

Further, it is worth stressing that only four countries such as Canada, Hungary, Slovak Republic, and Sweden have significantly positive coefficients for government consumptions in the cointegrating relationship, whereas Iceland, Italy, Norway, and Turkey show even negative ones, and the rest of countries have insignificant ones, implying that the expansionary fiscal policy in the OECD countries is not necessarily able to encourage the international trade. Iceland, which revealed serious banking sector problems in the recent financial crisis, is noticeable as having negative long-run elasticity of government consumption. At the time of writing this paper, the budget deficit in Iceland is running 13 $\%$ of GDP and public debt is over 100\%. Government consumption could be home-biased having little scope to spend on imported goods (Brulhart and Trionfetti 2009). As far as the euro area is concerned, it is noted that the 11 countries out of the 13 euro members among the OECD countries show insignificant coefficients for government consumption. Italy, one of euro member countries with high government debt burden, has significantly negative coefficient for government spending in the long-term relationship while only Slovak Republic has a significantly positive one. Slovak Republic has relatively sound fiscal records and recently(2005-2007) there have been even efforts to reduce overall share of public finance in the economy. But strong correlations between the government debts or deficits in the OECD countries and the coefficient signs for government consumption in our estimation are not observed in the consistent manner.

Interaction term between private and government consumptions in equation (2) is supposed to capture the non-separability of private and government consumptions and their possible influence on import demands. For instance, positive signs for interaction terms are likely to be related to complementary relationship between private and government 
consumption (Fiorito and Kollintzas 2004, Linnemann and Schabert 2004) in the sense that a positive shock to government consumption raises private consumption, possibly leading to increase import demands. In the same manner, in case with the sufficiently high substitutability between private and government consumptions, the signs for interaction terms could be negative, if not necessarily. In addition to this crowding-in versus crowding-out effects of government consumption against private consumption, the afore-mentioned macroeconomic financing aspects of government consumptions may affect private consumptions, which might be also reflected on the interaction term.

In contrast to the insignificant coefficients of government consumptions in the most of countries, the half of the OECD countries have significant interaction terms and the positive signs for the interaction term are the majority, suggesting complementary relationship between private and government consumptions, which is likely to raise import demands. Focusing on the euro area, the 7 out of 13 countries show significantly positive interaction term such as in Finland, Ireland, Italy, the Netherlands, Portugal, Slovak Republic, and Spain. It implies that expansionary fiscal policy is more effective in encouraging the world trade if it is in the way to boost private consumptions, certainly by more than offsetting all negative channels from the increases in government consumptions to private consumptions.

There is another point to make in relation to export and import volume estimates, i.e., Marshall-Lerner condition named after Alfred Marshall and Abba Lerner that is often presumed to be true in the international economic discussions but this paper finds that only in 9 out of 30 OECD countries, the Marshall-Lerner condition is held in the form of a long-run relationship. This condition states that currency devaluation can improve trade balance if the sum of price elasticity of export and import volumes is greater than unity in the absolute value terms.

According to our estimates in the long-term relationship, Marshall-Lerner condition is expected to be held in Czech Republic, France, Finland, Iceland, Japan, Korea, Mexico, Spain, and Switzerland. For the G7 countries, Japan was also listed in Nigel et al. (2005). Hence, it suggests that for most of the OECD countries, strategic exchange rate devaluations may deteriorate trade balances.

The dispersion of the long-run relative price elasticities is in the range 0 to -1.779 and the $21 \mathrm{OECD}$ countries are found to have insignificant long-term price elasticity in import volumes in contrast with in export volume results where only 9 countries have insignificant coefficients. It implies that in import volumes, scale effects reflected in the GDP components are more important determinants than price effects in explaining the long-term movements in import volumes.

Import volume trends have steadily risen over time towards 2015, a fact reflected on the trend components in the 18 countries - Australia, Austria, Belgium, Canada, Denmark, 
France, Germany, Greece, Hungary, Iceland, Italy, Japan, Korea, Luxembourg, New Zealand, Slovak Republic, Switzerland, the United States. It is a good sign of the world trade integration in that the majority of the developed countries such as the OECD economy, are serving their markets as the world export market in the increasing way against time.

\section{Export and Import Prices}

Nearly every economic question is a matter of degree and pricing-to-market behaviors and the related issues also fall into this category of the question as illustrated in figures 2 to 3 that show cross-country diversity among the OECD countries. Pricing-to-market is the core issue in our price equations to decipher the results for the macro-economy in that it is the question of pass-through of foreign prices and exchange rates that are the key elements in the open economy phenomenon and the related macroeconomic policies. Pricing-to-market effects arise through the limited pass-through of foreign prices and the exchange rates, meaning a violation of the law of one price and consequent segmentation of national markets, and thus generating the robustness of domestic prices from the external factors. So, the pricing-to-market is the other side of coin, i.e., cost-based pricing related to the law of one price or the purchasing power parity.

The basic export price equation with a cointegrating relationship is written in equation (3).

$$
\begin{aligned}
& d \ln \left(P X_{i t}\right)=\alpha_{1 i}+\alpha_{2 i} d \ln \left(P X_{i, t-1}\right)+\alpha_{3 i} d \ln \left(P W_{i t}\right)+\alpha_{4 i} d \ln \left(P W_{i, t-1}\right)+\alpha_{5 i} d \ln \left(P G D P_{i t}\right) \\
& +\left(1-\alpha_{2 i}-\alpha_{3 i}-\alpha_{4 i}-\alpha_{5 i}\right) d \ln \left(P G D P_{i, t-1}\right)+\alpha_{6 i} d \ln \left(E X_{i t}\right) \\
& +\alpha_{7 i}\left[\ln \left(P X_{i, t-1}\right)-\alpha_{8 i} \ln \left(P W_{i, t-1}\right)-\left(1-\alpha_{8 i}\right) \ln \left(P G D P_{i, t-1}\right)-\alpha_{9 i} t i m e_{t-1}-\alpha_{10 i} \ln \left(\text { time }_{t-1}\right)\right] \\
& +v_{i t}
\end{aligned}
$$

where $P X$ denotes the domestic currency price of exported goods and services in country $i, P W$ denotes the corresponding price of competitors' on export markets (see appendix), $P G D P$ is the GDP deflator in the domestic business sector, and $E X$ is the bilateral exchange rate of dollar per unit of host currency.

Pricing-to-market effects in the export price equation correspond to the extent to which exporters adjust their prices to the prevailing prices set by their competitors. In the export price equation, relative magnitudes of $\alpha_{8 i}, 1-\alpha_{8 i}$ are of our interests as it tells the 
pricing behavior of each OECD country as an exporter, that is, pricing-to-market $\left(\alpha_{8 i}\right)$ versus cost-based pricing $\left(1-\alpha_{8 i}\right)$. One can expect that a large open economy or an economy behaving like a large open economy in terms of price-setting power has greater estimate of $\left(1-\alpha_{8 i}\right)$.

Import price equation is written in equation (4).

$$
\begin{aligned}
& d \ln \left(P M_{i t}\right)=\beta_{1 i}+\beta_{2 i} d \ln \left(P M_{i, t-1}\right)+\beta_{3 i} d \ln \left(P S_{i t}\right)+\beta_{4 i} d \ln \left(P S_{i, t-1}\right)+\beta_{5 i} d \ln \left(P D_{i t}\right) \\
& +\left(1-\beta_{2 i}-\beta_{3 i}-\beta_{4 i}-\beta_{5 i}\right) d \ln \left(P D_{i, t-1}\right)+\beta_{6 i} d \ln \left(E X_{i t}\right) \\
& +\beta_{7 i}\left[\ln \left(P M_{i, t-1}\right)-\beta_{8 i} \ln \left(P S_{i, t-1}\right)-\left(1-\beta_{8 i}\right) \ln \left(P D_{i, t-1}\right)-\beta_{9 i} t i m e_{t-1}-\beta_{10 i} \ln \left(t i m e_{t-1}\right)\right] \\
& +\omega_{i t}
\end{aligned}
$$

where $P M$ denotes the price of imported goods and services excluding commodities in country $i, P S$ denotes the shadow price reflecting foreign producer's cost, $P D$ is the total domestic expenditure deflator reflecting domestic cost, and $E X$ is the bilateral dollar exchange rate, that is, dollars per unit of host currency.

The pricing-to-market effects in the import price equations can be interpreted as a measure of the robustness of domestic prices from possible pass-through effects of foreign prices and exchange rates in the import market $i$. The relative degrees of the pricing-to-market behavior $\left(1-\beta_{8 i}\right)$ versus cost-based pricing $\left(\beta_{8 i}\right)$ deserve our attention, since they indicate pricing tendency from the point of foreign exporters and the extent of national market segmentation from the rest of the world. Hence, the limitation to the pass-through in the import market arises because foreign exporters have to compete against domestic producers. The $P D$ term in the long run relationship is supposed to capture it, measuring the degree that foreign competitors have to align their prices to the prevailing domestic prices.

In both equations, the imposition of static and dynamic price homogeneity is decided after restriction tests. Static price homogeneity restrictions shown in $\alpha_{8 i}, 1-\alpha_{8 i}$ under export price equation and in $\beta_{8 i}, 1-\beta_{8 i}$ under import price equation, are derived at the microeconomic level for a profit maximizing firm subject to decreasing returns of scale, perfect competition in factor markets and less than perfect competition in its product market(Deppler and Ripley 1978).

Dynamic price homogeneity shown in the coefficient, $1-\alpha_{2 i}-\alpha_{3 i}-\alpha_{4 i}-\alpha_{5 i}$ under export price equation, and $1-\beta_{2 i}-\beta_{3 i}-\beta_{4 i}-\beta_{5 i}$ under import price one are required in order to ensure that relative price levels are ultimately independent of the steady state rate 
of price inflation (Nigel et al. 2005). The deterministic time trends are to capture omitted factors.

Price homogeneity is accepted by the data in the majority of the OECD countries in Nigel et al. (2005). In the current estimation of the export prices, however, considerable number of countries including Germany and the United States reject the restrictions imposed on export price equation. As for import price equation, the half of the OECD countries reject the constraints including the United States. So, the estimation proceed with the incorporation of the parameter restriction test result for each country.

Because of the countries' various responses to the parameter restriction tests, the sum of coefficients for the world price and the GDP deflator in equation (3) and the sum of coefficients for the foreign shadow export price and domestic expenditure deflator in equation (4) are not necessarily equal to unity as specified in equations (3) and (4), however, we can still compare the relative magnitudes of pricing-to-market versus cost-based pricing whether the equation is restricted or not.

The degree of pricing-to-market also has the implications of the exchange rate pass-through effect on import price. Notable example would be found in the US dollar depreciation after the Plaza accord in 1985. The US dollar depreciation did not immediately affect the US import price due to the pricing-to-market behaviors by foreign exporters who reduced profit margins to protect market shares in the US market. Under the law of one price, exchange rate provides an expenditure-switching effects and trade balance adjustment mechanism. Thus, the coefficient of the dynamic exhange rate term in our price equations is expected to be negative if expenditure-switching effects are operating from the beginning. The separate dynamic terms of the exchange rates in the short-run dynamics allow us to test whether the initial response to nominal exchange rate fluctuations, differs from the initial response to the changes in foreign shadow prices. The estimate of the coefficient, $\beta_{3 i}$ is expected to be positive, and that of the coefficient, $\beta_{6 i}$ is expected to be negative if their initial responses are the same.

Figures 2 and 3 show the cross-country spectrum of pricing-to-market in the aggregate cases. In the export price results where the OECD countries can be viewed as exporters, large degree of adjusting to producer's cost in Norway is observed. Canada is the country with the greatest pricing-to-market. In our sample of the OECD countries, greater cost-based pricing than pricing-to-market is the majority except Belgium, Canada, Czech Republic, Denmark, France, Korea, New Zealand, Poland, Turkey, and the United Kingdom. The majority of the euro member countries within the OECD economy, again show greater cost-based pricing except Belgium, France and the Netherlands.

In the import price equations where the OECD countries are to be viewed as import markets, Japan, the United States, and Norway show the largest degree of pricing-to-market 
and supposedly to experience the domestic price robustness from the penetrations of foreign prices or/and exchange rate changes but might have had the volatile exchange rate movements given the lack of import price adjustment mechanisms according to the model in Betts and Devereux (2000).

Only France, Greece, Japan, Norway, Slovak Republic, and the United States show greater pricing-to-market in their import markets compared to producer cost-based pricing. Most of the euro member countries have larger foreign producers' cost-based pricing than pricing-to-market in their import markets. In this regard, the institutional idea in the euro area where more flexible price and wage mechanism in order to encourage productivity and prosperous economy at the expense of a devaluation option for each member, appears to be operating.

\section{Conclusion}

The points discussed in this paper are often related to the key assumptions and elasticities in the international macroeconomic models and discussions. Cross-country diversity as well as the generality within the OECD economy are found in the trade system estimations over the period from the first quarter of 1982 to the fourth quarter of 2008.

In general, the export volumes in the OECD economy becomes more price elastic in the current estimation over the period of 1982 to 2008 than the previous estimation over the period of 1982 to 2002. Only 9 member countries have insignificant role of relative export price variables in explaining the long-term movements of export volumes. On the other hand, in the import volume results, the 21 OECD countries are found to have insignificant long-term price elasticities in import volumes, implying that scale effects reflected in the GDP components and/or trend parts are more important than price effects in explaining the long-term import volumes.

Error correction terms are mostly significant suggesting the presence of the long-term relationships in each trade equation. Time trend component is expected to capture omitted factors and to reveal variations over time. Decreasing trend of export volumes, increasing trend of import volumes, decreasing trend of export and import prices towards the year 2015 are found to be the majority among the OECD countries which have significant trend components.

Macroeconomic policy implications can be summarized as follows. 
First, referring to the Marshall-Lerner condition and our estimates, the strategic exchange rate depreciation policy would be effective for the 9 OECD countries such as Czech Republic, Finland, France, Iceland, Japan, Korea, Mexico, Spain, and Switzerland but for most of the OECD countries, it seems not to serve to improve their trade balances in the long run.

Second, not every GDP component is significant in explaining import volume in the long run relationship. Investment demands generally have more significant explaining power than private and government consumptions, which shows one facet of linkages between the international trade and the macro-economy.

Third, the increases in government spending does not necessarily encourage the world trade in that it is non-separable with private consumption except Canada, Hungary, Slovak Republic, and Sweden. Even negative impacts of government spending on the world trade are possible if one considers the financing aspect of fiscal expansion and substitutability between private and public goods. In fact, personnel expenses takes more than $50 \%$ on the average of the OECD countries. So, if postive shocks to government consumption is in the way of increasing private consumption, then the world exports can be heartened - Czech Republic, Finland, Ireland, Italy, Korea, the Netherlands, Norway, Portugal, Slovak Republic, Spain, Sweden, Turkey, and the United Kingdom are the cases.

Fourth, in the picture of the pricing-to-market behaviours across the OECD countries as exporters, Norway reflects her producer cost the most in her export price among the OECD countries whereas France, Korea, and the Netherlands show the complete pricing-to-market behaviours with insignificant coefficients for producer cost terms.

Fifth, penetration of foreign prices or exchange rates have the macroeconomic policy implications. Foreign exporters show pricing-to-market behaviours in the import markets of Japan, the United States, and Norway in the order of the magnitudes. Japan, Norway, and the United States may have relatively stable import prices from external forces.

Sixth, most of the OECD countries as exporters have aligned to their producing costs more than the world prices, and as import markets, the majority of the OECD countries show greater cost-based pricing than pricing-to-market, even if there are clear evidence of pricing-to-market with cross-country diversity in both export and import prices. Interestingly, if one sees the OECD countries as exporters in the export price equation, more than 10 countries show greater pricing-to-market behaviors compared to cost-based pricing behaviors but if one treats them as markets as designed in the import price equation, far less than 10 countries show greater pricing-to-market compared to the cost-based pricing in their import markets. 


\section{References}

Angeletos, G. M. and Vasia, P. (2009), Revisiting the Supply side effects of Government Spending, Journal of Monetary Economics, 56: 137-153

Betts, C. and Michael, B. D. (2000), Exchange rate dynamics in a model of pricing-to-market, Journal of International Economics 50: 215-244

Blanchard, O. and Roberto, P. (2002), an Empirical Characterization of the Dynamic Effects of Changes in Government Spending and Taxes on Output, The Quarterly Journal of Economics, 1329-1368

Blinder, A. S. and Solow, R. M. (1973), Does Fiscal Policy Matter?, Journal of Public Economics 2: 319-337

Brulhart, M. and Federico, T. (2009), A test of trade theories when expenditure is home biased, European Economic Review, available online since 21 March 2009

Bussiere, M., Alexander, C., Giulia, S. (2009), Modelling Global Trade Flows: Results from a GVAR Model, European Central Bank working paper series No. 1087

Canzoneri, M., Cumby, R., Diba, B. (2002), New views on the transatlantic transmission of fiscal policy and macroeconomic policy coordination, mimeo, Georgetown University

Deppler, M. C., and Ripley, D. M. (1978), The World Trade Model: Merchandise Trade, Staff Papers (International Monetary Fund, Washington DC: International Monetary Fund

Ganelli, G. (2007), The Effects of Fiscal shocks on Consumption: reconciling theory and data, The Manchester School 75(2): 193-209

Ganelli, G. and Juha, T. (2009), Can Government Spending Increase Private Consumption?; the role of complementarity, Economics Letters, 103(1): 5-7 
Gilbert, C. L. and Theodosioa, B. P. (1990), "Modelling expectations formation in Primary Commodity Markets in chapter 3 in Primary Commodity Prices: Economic Models and Policy, eds. by L. Alan Winters and David Sapsford, Cambridge University Press

Fiorito, R. and Tryphon, K. (2004), Public goods, Merit goods, and the Relation between private and government consumption, European Economic Review 48: 1367-1398

Haas, R. D. and Anthony, G. T. (1990), The World Trade Model: Revised Estimates, Journal of Policy Modeling 12(1): 93-128

Linnemann, L. and Andreas, S. (2004), Can fiscal spending stimulate private consumption?, Economics Letters 82: 173-179

Nieh, C. C. and Tsung-wu Ho (2006), Does the expansionary government spending crowd out the private consumption? : cointegration analysis in panel data, 46: 133-148

OECD (2003), OECD Science, Technology and Industry Scoreboard

OECD (2008), Globalisation and Emerging Economies: Brazil, Russia, India, Indonesia, China and South Africa

Olivei, G. P. (2002), Exchange rates and the prices of manufacturing products imported into the United States, New England Economic Review, first quarter: 3-16

Pain, N., Annabelle, M., Franck, S. and Laurence, L. F. (2005), The New OECD International Trade Model, OECD Economics Department Working Papers No. 440

Ravn, M., Stephanie, S. G. and Martín, U. (2006), Deep Habits, Review of Economic Studies 73: 195-218

Spencer, G. H. (1984), The World Trade Model: Revised Estimates, Staff Papers (International Monetary Fund, Washington, DC), 31(3): 469-698 


\section{Appendix. Definition of Variables}

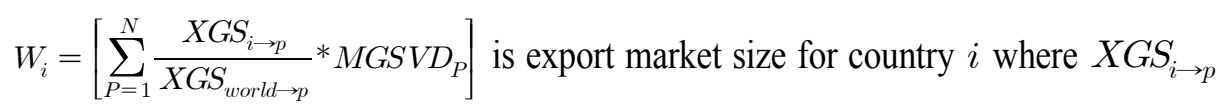
is the export values of goods and services from country $i$ to country $p, X G S_{w o r l d \rightarrow p}$ is the global export values of goods and services to country $p, M G S V D_{P}$ is import volume of country $p$, expressed in 2005 US dollar and the year 2005 as the base year.

$$
P S_{i}=\left[\sum_{P=1}^{N} \frac{X G S_{p \rightarrow i}}{X G S_{\text {world } \rightarrow i}} * P X_{P} * E X C H I N_{P}\right] * \frac{1}{E X C H I N_{i}} \text { is the foreign price indicator for }
$$
the country $i$, and it is expressed as the shadow price of its $N$ partner counties where $P X_{p}$ is the non-commodity goods and services export price for country $p, 2005=1, E_{X X H N_{P}}$ is the exchange rate index for country $p$ with $2005=1$.

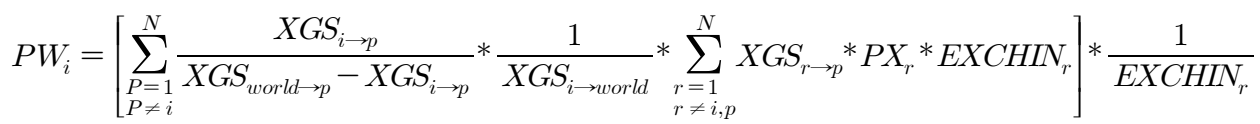

is the competitors' price concept based on goods and services prices excluding commodity prices.

Also for all product case in estimating export and import price equations, export price, import price, foreign shadow price, competitor price are constructed in the same manner.

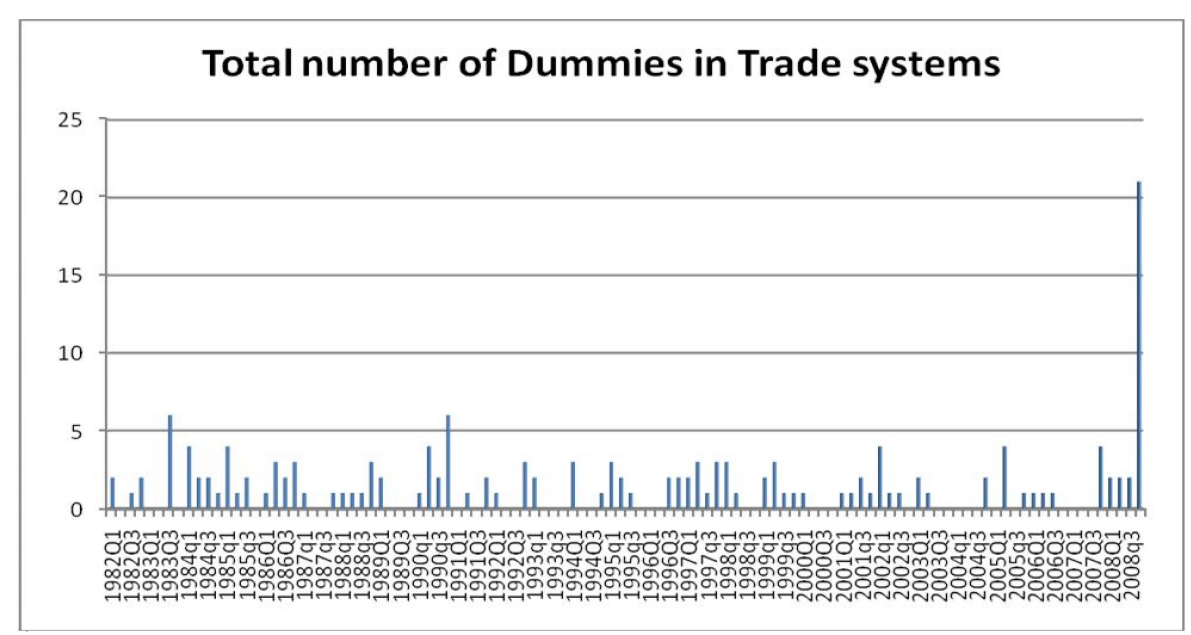

Figure 1.

Dummies 


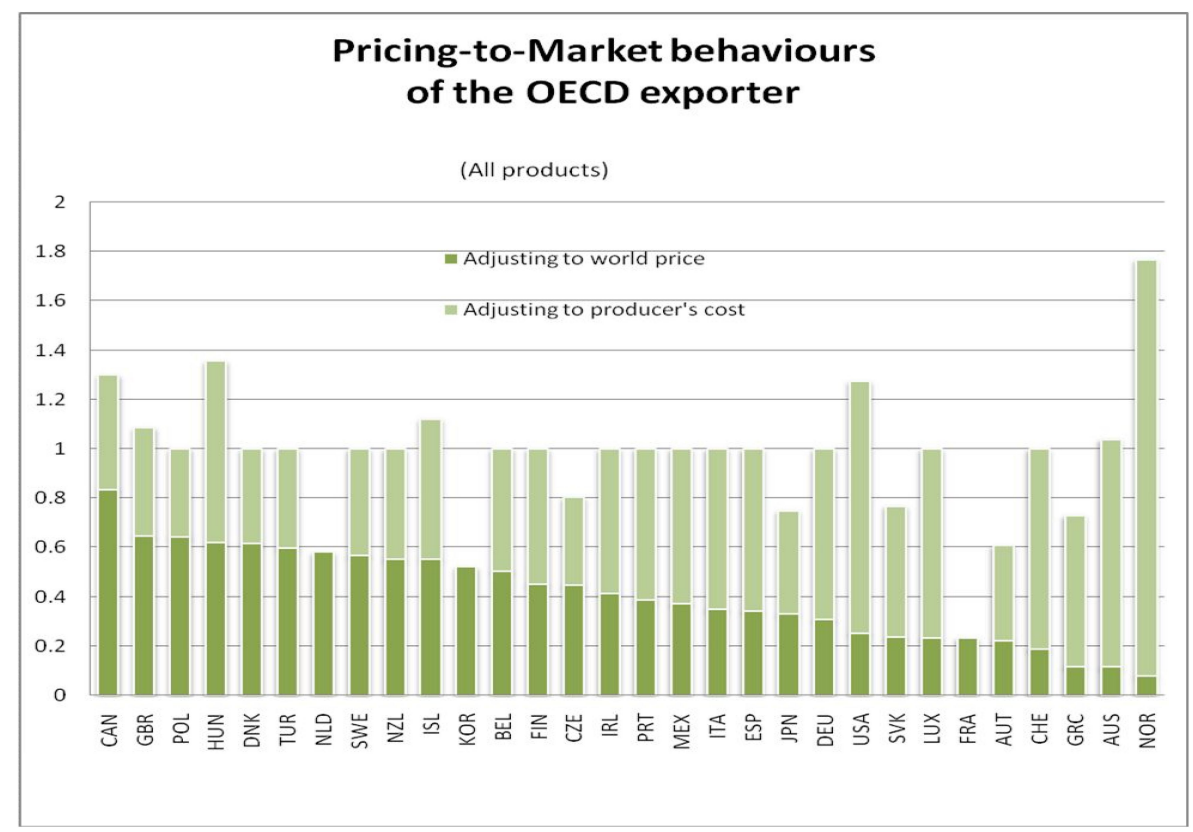

Figure 2.

(Note) AUS: Australia, AUT: Austria, BEL: Belgium, CAN: Canada, CHE: Switzerland, CZE: Czech Republic, DEU: Germany, DNK: Denmark, ESP: Spain, FIN: Finland, FRA: France, GBR: United Kingdom, GRC: Greece, HUN: Hungary, IRL: Ireland, ISL: Iceland, ITA: Italy, JPN: Japan, KOR: Korea, LUX: Luxembourg, MEX: Mexico, NLD: the Netherlands, NOR:Norway, NZL: New Zealand, POL: Poland, PRT: Portugal, TUR: Turkey, SVK: Slovak Republic, SWE: Sweden, USA: United States 


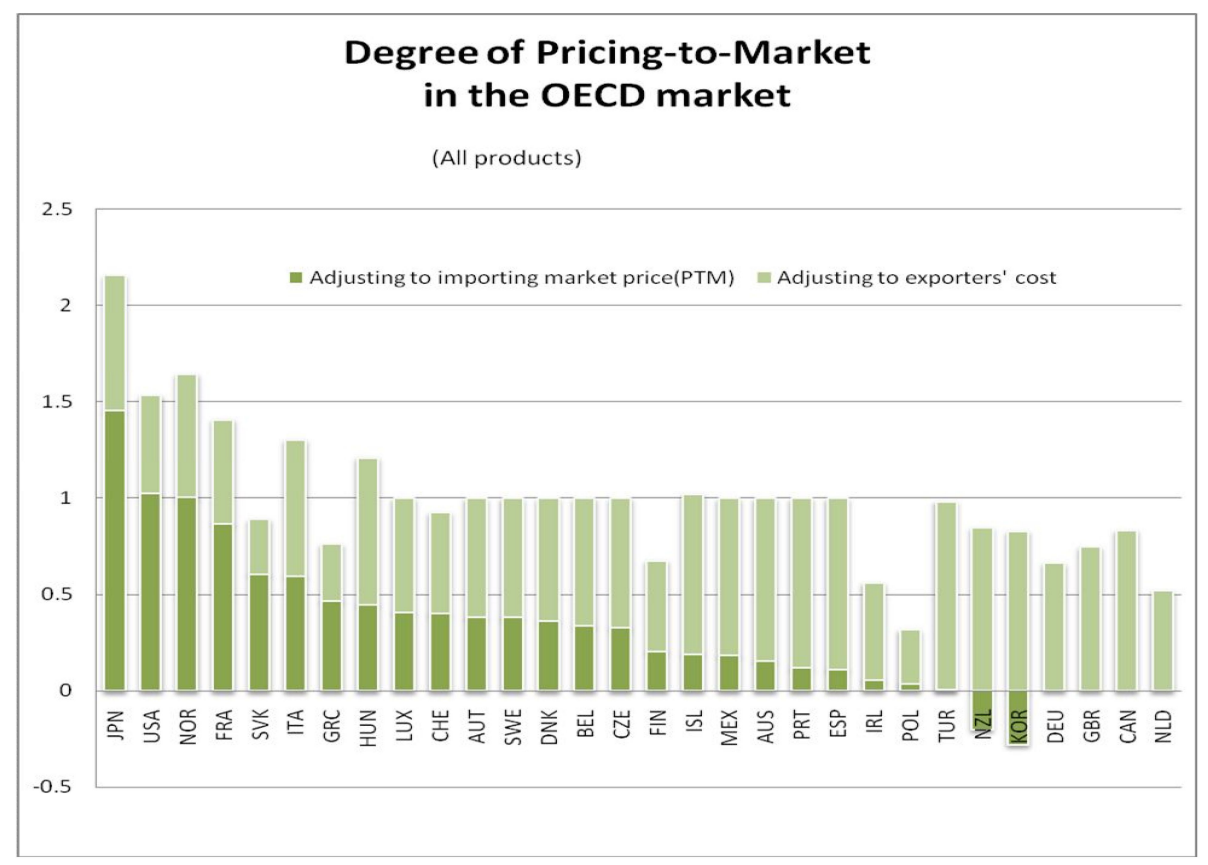

Figure 3.

(Note) AUS: Australia, AUT: Austria, BEL: Belgium, CAN: Canada, CHE: Switzerland, CZE: Czech Republic, DEU: Germany, DNK: Denmark, ESP: Spain, FIN: Finland, FRA: France, GBR: United Kingdom, GRC: Greece, HUN: Hungary, IRL: Ireland, ISL: Iceland, ITA: Italy, JPN: Japan, KOR: Korea, LUX: Luxembourg, MEX: Mexico, NLD: the Netherlands, NOR:Norway, NZL: New Zealand, POL: Poland, PRT: Portugal, TUR: Turkey, SVK: Slovak Republic, SWE: Sweden, USA: United States 